\title{
The shift to the subject in 20th century philosophy of science: A liberating move?
}

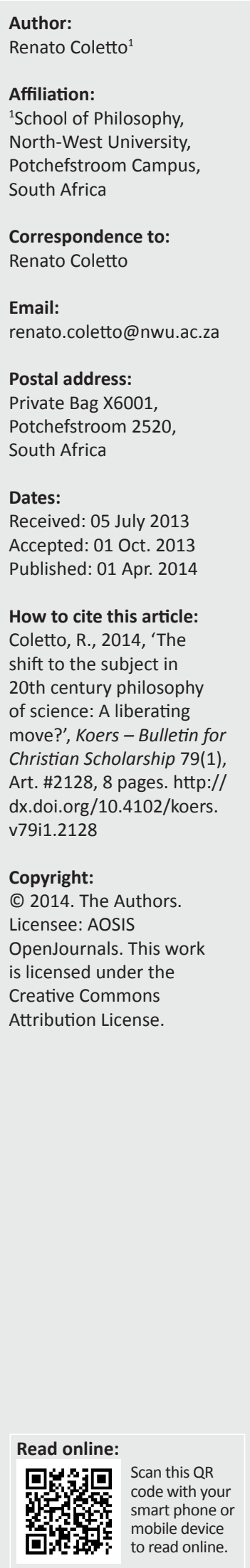

During the 20th century, the 'subject' of knowledge (i.e. the individual scientist or a scientific community) was attributed an increasingly relevant role in (the philosophy of) science. Anchoring scientific knowledge to the subject (rather than to the object, as in early positivism) was proposed as a 'liberating' move, leading to a less authoritarian and rationalistic view of science. This article provides a reformational point of view on the topic. A historical documentation of the shift to the subject is provided by visiting the philosophies of Popper, Kuhn, Collins and others. It is argued that the promise of a more libertarian or emancipating conception of science was challenged by several problems. In particular, the conflict between an individual and a communal understanding of the subject is highlighted. Furthermore, it is argued that the roots of the phenomenon in most cases remain hidden. An interpretation of the shift and the sketch of an alternative approach conclude the article.

Die skuif na die subjek in die 20ste eeuse wetenskapsfilosofie: 'n Bevrydende verskuiwing? Gedurende die 20ste eeu is toenemende relevansie in die (filosofie van die) wetenskap toegestaan aan die 'subjek' van kennis (i.e. die individuele wetenskaplike of 'n wetenskaplike gemeenskap). Die verankering van wetenskaplike kennis tot die subjek (eerder as tot die objek, soos in vroeë positivisme) is as ' $n$ 'bevrydende' verskuiwing voorgestel wat aanleiding gee tot ' $n$ minder outoritêre en rasionalistiese siening van die wetenskap. Die verskuiwing na die subjek word histories gemotiveer deur die filosofieë van Popper, Kuhn, Collins en ander te besoek. Dit word geargumenteer dat die belofte van 'n meer liberalistiese of emansiperende opvatting van die wetenskap deur verskeie probleme gekonfronteer is. Veral die konflik tussen 'n individuele en 'n kommunale verstaan van die subjek word beklemtoon. Boonop word dit geargumenteer dat die wortels van die verskynsel in die meeste gevalle versteek bly. Die artikel word afgesluit met ' $n$ interpretasie van die verskuiwing en die buitelyne van ' $n$ alternatiewe benadering.

\section{Introductory notes}

For a long period since the 1850s, science seemed to rely on the facts, and facts seemed to speak for themselves. Especially in the early positivist period, the facts, their observation and 'collection' were supposed to lead to objectivity and certainty. The best 'role' the subject of scientific research (either an individual or a community) could play was to stay out of the picture as much as possible. No personal or group prejudices (religious or metaphysical) were allowed in the laboratory or in the study-room. All this was perceived by many as liberating: it would have opened the way to scientific truth (which was the only truth), and it would have created progress and consensus.

At a certain point, however, this approach began to be perceived as almost 'oppressive'. There was something authoritarian in its rationalism, perhaps in its a-historical approach, and (in Botha's 1988:43 words) a 'revolt against positivism' took place ${ }^{1}$. The revolt involved discussions of discoveries and justifications, evidences and theories and a whole conglomeration of specific topics. Basically, however, the revolt could be characterised as a shift: scientific knowledge was gradually anchored in the knowing subject (and not in the objects anymore). One could say that the subject was regarded as the new locus ordinis ${ }^{2}$ for reality in general and for science in particular. Again, the new approach was regarded as 'liberating', as leading to a more 'humanitarian' (Feyerabend's term) type of science.

This article tries to explore this 'shift' and to evaluate it. In my opinion, a proper recognition of the role of the subject in science is necessary. However, the 'revolt' against positivism did not result in liberation but was confronted by inner tensions which need to be pointed out and examined. Although this article does not try to examine all the possible problems created by (or

\footnotetext{
1.The emergence of anti-positivist arguments can of course be comfortably traced since the early 1930s in the works of Popper. However the 'revolt' was anticipated to an extent by authors like Duhem or Poincaré in the first two decades of the 20th century.

2.Latin: 'the foundation or source of order'
} 
related to) the shift to the subject in philosophy of science, it points out some problems that have not been discussed before, in particular the tension between an individualist and a communalist understanding of the knowing subject. In addition, it is argued that the roots of the phenomenon in most cases remain hidden to both secular and Christian scholars.

This article displays several examples to illustrate and observe the process and its consequences. Afterwards, a few clarifications and reflections are followed by my evaluation and interpretation of the shift. All analyses are conducted along reformational lines. The historical survey begins with Popper, whose philosophy can be regarded as a 'bridge' between positivism and some of the subsequent and more subjectivist philosophies of science.

\section{Popper}

One of the first recognitions of the role of the subject comes with Popper's philosophy. Compared to later developments, his recognition is rather timid and accompanied by frequent amendments. In fact, Popper retains something of the positivist heritage. One may think for example of his argument that 'scientific knowledge may be regarded as subjectless' (Popper 1970:57; 1979:106-152). He argues that the subjectivist theory of knowledge fails for various reasons. (...) it naively assumes that we cannot speak of knowledge without a knower, a knowing subject' (Popper 1983:92). Yet in the case of a logarithmic table, for example, 'there is nobody who "knows" the table', says Popper, 'yet the table represents "knowledge", objective knowledge (...). This knowledge is not "known" to anybody (not even to the compiler); it is only available' (Popper 1983:95). In these pronouncements the influence of positivism appears to be relevant still.

According to Popper (1961:155-159), it is futile to try to anchor scientific certainty and objectivity in the individual scientist, in the community of scientists or in the psychic or social characteristics of the human nature. Objectivity cannot depend on the subject of knowledge: in his view this 'naive solution' does not offer any guarantee for objectivity, which must rather be anchored in the objects of scientific enquiry (Popper 1961:155). In Popper's philosophy, though the universals are presupposed, the anchor of scientific certainty is sought mainly in the facts and as a consequence truth is defined as 'correspondence to the facts' (Popper 1963:224).

Yet apparently this is not the whole story. Compared to previous authors, in his philosophy the subject emerges with more decision and gains a legitimate role. I would say, for example, that deductivism (adopted by Popper) places the subject in a more prominent position than inductivism. With inductivism the facts speak first, and the task of the scientist is to accumulate a sufficient quantity of them so that they can almost 'dictate' our theories. By contrast, the deductive method starts from problems, hypotheses and expectations (and only the subject has problems or develops conjectures).
The result is that the scientific community plays an important role in Popper's philosophy. Not the individual but the community. He argues: 'science and more especially scientific progress are the results not of isolated efforts but of the free competition of thought' (Popper 1961:154-155). The scientific community is essential for the selection of problems, for proposing new theories, for mutual criticism and for falsification. In conclusion, Popper's philosophy is one of the places where the role of the subject (as community) begins to emerge with force. At this stage, however, one still finds a fair balance, a sort of harmony between individual and community. Polanyi's approach acknowledges the importance of the subject even more, but in his opinion the scientific subject is not only communal.

\section{Polanyi \\ The subject as a bridge}

The difference between Popper's and Polanyi's philosophies can be captured in the titles of some of their most famous books. Whilst Popper (1979) wanted to achieve Objective knowledge, Polanyi (1958) promoted the idea of Personal knowledge. Polanyi is a difficult author: some regard him as a realist (cf. Scott 1985), whilst others consider him a postmodern nominalist (Gill 2000). My impression is that Polanyi's philosophy underwent two phases, first a 'conservative' one and then a 'postmodern' one (Coletto 2007:74:fn. 53, 54). In any case, I would say that the shift to the subject continues in his philosophy as well. The example that I would like to provide for this argument concerns scientific discovery.

Scientific discovery, for Polanyi, is not first of all a matter of critical rationality but a matter of personal commitment. In the scientific activity this commitment discloses itself according to its original tacit structure. According to Polanyi, problems are basic to science, but personal commitment and interest are basic in the selection of problems. In fact, 'nothing is a problem or discovery in itself; it can be a problem only if it puzzles and worries somebody' (Polanyi 1958:122). The selection of a problem entails in itself a certain risk, for example one could select a problem that is too demanding (ibid:124). But most importantly the selection of a problem discloses a 'logical gap' (ibid:123). This is the gap that must be crossed by solving the problem, but there is no formalised logical procedure to solve the problem or to make an important scientific discovery. The latter can never be traced by a logically connected sequence of determinable steps. True discovery implies an un-specifiable element. The presence of certain elements of unspecifiability, originality and personal risk in discovery points towards the notion of tacit knowing. Originality is not only necessary in the process of discovery but is also the true and characteristic mark of discovery.

However, the important question is: What is the decisive factor to cross the logical gap? At one specific instance Polanyi (1958:123) speaks of 'illumination'. More generally he maintains that intellectual passions are the key factor and 
are directly linked to personal commitment. The commitment of the person is the key factor to cross the gap, in this case a gap between a hidden reality and a committed knower. The subject, therefore, emerges as the bridge between problem and discovery.

In another text (Coletto 2007:35ff.), I have discussed another theme of Polanyi's philosophy, pointing in the same direction. It is namely that the subject is also a bridge between individual clues and the formation of universal concepts (cf. Polanyi 1974:171). Once again, it is the subject who bridges the gap and acquires a new place in science.

\section{The personal subject}

As far as the role of the subject is concerned it must be admitted that Polanyi succeeds in maintaining a fair balance between individual scientist and community. Yet within this balanced position I would say that more emphasis is gradually placed on the individual.

In his initial writings one can observe the considerable role given to 'tradition', authority and to the community of science. The transmission of knowledge from one generation to the next (i.e. tradition) is almost sacred; it is defined as 'a sort of apostolic succession' (Polanyi 1946:44). The individual who joins the tradition initially can only adapt to it and be formed by it. Nevertheless, one's independence from a 'master' gradually grows and one's conscience needs to become the final judge by which decisions are taken. There is no pope in science, says Polanyi (ibid:56ff.), in the sense that authority is not centralised but 'distributed'. No authoritarian party should be allowed to dictate the lines along which research should develop or solutions should be sought. Here we have the important theme of the harmony between 'authority and conscience' (ibid:42-62).

This theme is developed by Polanyi in connection with dramatic life-experiences. He suffered the invasion of his country, Hungary, by Soviet troops. Twenty years earlier, he had experienced first-hand the effects of state-controlled research when visiting some colleagues and friends in the former Soviet Union. He also followed developments such as the Lysenko affair, Vavilov's persecution, and the theme of academic freedom of conscience became a key issue in his philosophy of science (Polanyi 1946:7-9).

It became crucial, for Polanyi, to oppose scientific freedom to state-directed research. From this point of view, the shift to the subject could only appear as liberating. But this freedom was not only individual, it was freedom for the community as well. He did not simply juxtapose the individual to the community but examined the principles leading to freedom and those leading to servitude. Once again, I would say that at this stage we still find a fair balance between individual scientist and community. It should be observed, however, that in later authors the dialectical tension between individual and community became more polarised.

\section{Kuhn \\ Paradigm and community}

The anchor of certainty is placed in the human subject of knowledge by Kuhn as well. Actually, Kuhn's work brings the shift to the subject one step further. During the 1970s, the Popperian school considered Kuhn's emphasis on the scientific community as being definitely excessive. Kuhn was even accused of justifying 'mob psychology' (Lakatos 1970:140fn. 3, 178). In other words, he was accused of presuming that whatever the community says is the truth for a certain time and context. Although this problem is not analysed here (it has been sufficiently discussed) it constitutes a fundamental threat to the promise of a liberating type of science.

Kuhn (1970b:260-263) defended himself from those allegations by saying they were based on misunderstandings of his views. But although he was not promoting mere arbitrariness, he had certainly moved to a more relativist position. He had to recognise that his position boils down at least to partial relativism (ibid:264-265) (a position that Bernstein would call 'partial subjectivism'3).

To acknowledge this move it is sufficient, for example, to look at the paradigm concept and to realise how dependent on the subject of knowledge it is. Each paradigm is the achievement of a scientific community and without community there is no paradigm. A paradigm ends the controversies amongst the schools of the pre-paradigmatic phase of science and establishes the consensus of a scientific community. In fact, initially the paradigm concept was elaborated by Kuhn to account for the consensus of a scientific community. The phases that in The structure are called 'pre-paradigm' and 'paradigm' periods (Kuhn 1996:47, 63), were previously defined as 'pre-consensus' and 'firm consensus' phases (Kuhn [1959] 1977:231-232).

The paradigm concept is so tied to the community concept that Kuhn (1996:176) can say: 'a paradigm is what the members of a scientific community share, and, conversely, a scientific community consists of men who share a paradigm'. Although Kuhn will later specify and modify this basic idea, its fundamental meaning will remain unchanged.

Admittedly, for the purpose of recognising Kuhn's subjectivism it is not important whether the emphasis is placed on an individual or a collective subject. One can safely say, however, that in Kuhn the communal dimension is dominant.

\section{The communal subject}

In this respect, it is time to start noticing one disturbing consequence of the 'shift'. When the scientific community becomes the 'initiator and sanctor' (Botha's 1994:21 expression) of scientific legitimacy, the individual scientist

3.Bernstein (1985) ties together relativism and subjectivism: norms, truths and knowledge are always related (hence relative) to a certain culture, time and community (subject). 
seems to become powerless. He/she cannot oppose, for example, the ineluctable historical processes leading to a new paradigm. What he/she can do, together with a few others, is to stick to the old paradigm, but the cost is that he/she will cease to be regarded as a scientist (Kuhn 1996:18-19).

Popper (1970:54), who valued the community more than individuals, could still reserve his enthusiasm for the achievements of individuals like Darwin or Einstein. But according to Kuhn (1970a:6), such contributions are rare events. Busy with puzzles as his/her main occupation, the 'normal' scientist is usually not prepared to deal with radical innovations, not even to evaluate them. In addition, even genial achievements need to be endorsed by a community of colleagues otherwise they will mean simply nothing.

It is always the decision of the group that counts. Each new paradigm will simply cancel the previous one. It will not constitute an alternative that can be adopted alongside other paradigms. The principle of proliferation is welcomed only when a new paradigm is needed, after which it disappears and only tenacity (i.e. sticking to that paradigm) is left. Against these rather authoritarian traits of Kuhn's philosophy, Feyerabend raised his protest.

\section{Feyerabend}

\section{The 'happiness of the individual'}

I trust it is not necessary to demonstrate that Feyerabend is a subjectivist. But does he rely on the individual or on the community? In line with his anarchism, he prefers the individual. Even the purpose he assigns to science is in line with this: 'the aim of science is to promote the happiness of the individual and the satisfaction of his manifold needs' (Feyerabend 1970:210).

Feyerabend condemns all forms of authoritarianism and pledges plurality and freedom. Proliferation of theories and tenacity (the possibility of retaining refuted theories or perspectives) are his ideal. No scientific 'truth', no theory should be imposed on all. One should always be careful to respect all views: for example, some believe that the Earth moves around the sun, but others do not agree (Feyerabend 1975:301). Unlimited pluralism of theories and methods: this chaos is the only way to generate progress, whilst consensus and traditionalism would surely kill it. This is why, in his typically colourful language, Feyerabend (ibid:188) attacks those scientists who behave like 'human ants', always ready to please a boss for the sake of a decent salary. They do not dare contradict anybody and so they betray pluralism and freedom.

\section{Authoritarian individualism?}

And yet, Feyerabend's (1975:28, 32) works contain strange arguments as well. He can argue, for example, that when it comes to methods 'anything goes'. But he can also recommend one method as preferable (ibid:27), actually as the most suited for science (ibid:190), 'the right method' (ibid:66), the only method that can produce real progress. This is the 'anthropological method' (ibid:252), directly inspired by anarchism. For the moment it is still early for the scientific community to adopt it ('it is liable to paralyse the brains of almost everyone' - ibid:214). But one day these truths will be acknowledged by all and the anthropological method will triumph. One might ask: and what will happen to pluralism then?

Pluralism is so important that it must be defended at all costs. Even at the cost of imposing it? Feyerabend (1975:50-53) praises, for example, the Chinese government for breaking the monopoly of Western medical science and forcing the reintroduction of traditional Chinese medicine in their country. In some cases it might be necessary to enforce pluralism (or at least dualism), even by violence (ibid:187), so that individual freedom may become collective freedom. Even the scientific community needs to be controlled from outside by the state, or by whatever institution can keep its power in check (ibid:216).

These are a few curious consequences of Feyerabend's radical pluralism and individualism. The shift to the subject is so liberating that even those who do not want it (to borrow Rousseau's famous phrase) 'will be forced to be free'! Curious developments indeed: is it possible that even the liberating shift to the (individual) subject may acquire authoritarian traits?

Whilst Feyerabend was busy searching for a locus ordinis, especially in the ever-changing stream of history, the philosophy of science also experienced a sociological turn. In the following section I briefly analyse a representative of this trend in order to substantiate the claim that he strengthened the shift to the subject and a totalitarian view of the scientific community.

\section{Collins}

\section{The locus of order is society}

Whilst Feyerabend insisted on the role of the individual for Collins it is the scientific community that constitutes the order of the world that scientists explore. Collins is part of a larger movement that initiated the 'sociological turn' (Botha 1994:22). His Empirical Programme of Relativism is closely related to the Edinburgh School of the Sociology of Knowledge. Amongst the most representative figures of this 'turn' are Brown (1984), Barnes, Bloor and Henry (1995) and Collins (1992).

Collins challenges the common-sense assumption that there is an order of or for reality that does not change, that shapes scientific theories, and that can (to a certain extent) be represented by those theories. According to Collins the essence of this order is rather social. Because there are communities that explore such order and share a certain language, we experience uniformities and regularities. Yet it is not the order that constitutes the possibility of a common language and of a scientific community. It is just the opposite. 
The existence of a scientific community is the origin of the perceived order (Collins 1992:5). Collins (ibid:148) states it in a very succinct way: 'the locus of order is society'.

Collins sets out to demonstrate that the origin of replication in science has a sociological foundation. He explores the case of the TEA-laser (for experiments in gravitational radiation) and two studies on paranormal phenomena. Through detailed observations he shows that the object of scientific enquiry has very little relevance in shaping our conclusions. What really matters is our perception. We perceive regularities and order, we expect the future to be like the past. But, asks Collins (1992:6), is there any guarantee that our 'inductive inferences - generalisations from past experience - can ever be certain or even probable?' Collins invites the reader to remember Hume's lesson about causality. We see the movement of a billiard ball across the table and we are inclined to say that the ball is propelled by another ball. Its movement is 'caused', so our experience tells us. But, asks Collins (1992), supposing that the regularity of the $\mathrm{a}-\mathrm{b}$ sequence were just an extended coincidence, 'How would we see the difference?':

In other words, what is it that we see in the impact of the billiard ball that makes us view it as a casual relationship (...) rather than an extended coincidence, which we could not expect to continue? The answer is: nothing. (p. 7)

If we want to be able to solve this type of dilemma, according to Collins, we must look carefully into our social life and our language. The two are so intermingled that our habits of speech help determine the way we see the world and thus help form the basis for social interaction (Collins 1992:11). It is exactly there that our attention should focus. We perceive regularity and order because any perception of irregularity in an institutionalised context is translated by ourselves and by others as a fault in the perceiver or in some other part in the chain of perceptions (ibid:147). Scientific rules are only rules by virtue of social conventions (ibid:145).

\section{Authoritarian communalism?}

But is there some room then, it might be asked, for extraordinary contributions created by brilliant individuals who dare to go against the social network and its settled conventions? In other words, does Collins give a solution to the problems already experienced by Kuhn on this point? Collins (1992:148) admits that 'it is only individuals who can provide the material for conceptual change'. But an individual's act of creativity is nothing unless it becomes institutionalised. Even in this case, the wider 'network' and the wider society provide the conditions for the success of some new institutions but not others. 'Man proposes but society disposes', says Collins (ibid:149). Curiously, in his statement 'society' substitutes the 'God' of the original proverb. Indeed Collin's social networks explain everything, cause everything yet are in their turn not dependent on anything or needing any explanation. They fulfil the conditions to be considered what Clouser (2005:22-23) calls 'the divine'.

\section{One further problem}

To be sure, we could extend this article further. Examples of the shift to the subject would still be abundant for example in feminist philosophy of science or in Bruno Latour. David Hull, too, dealt extensively with these issues. ${ }^{4}$ However, I trust the above discussion is sufficient to demonstrate the existence of the trend and to illustrate some of its problematic traits. We could also insist on many other problems ${ }^{5}$ created by the shift to the subject and concerning science. However, I will point out only one more problem which is more fundamental than others and which reformational philosophy is particularly equipped to discuss. This problem does not concern only the individualists or the collectivists endorsing the shift to the subject. On the contrary, it affects both trends. The problem is that the shift to the subject was rarely presented for what it is.

Perhaps only Feyerabend (1985:xiii) dared to mention the fact that the shift corresponds to a 'preferred form of life', thus pointing towards its pre-theoretical commitments. The vast majority of the philosophers of science just preferred to describe it as a move generated within their discipline and to be understood within categories belonging to this discipline. In the next sections I will argue that this position is un-plausible. I will then proceed to an evaluation and interpretation of the shift. Before reaching that stage, however, a couple of clarifications are in order.

\section{What can be done? Some clarifications and reflections}

Firstly, I have not argued that the shift to the subject was accepted by all, was simply un-challenged and that no rival tendencies appeared on the scene. There surely are, even in contemporary philosophy of science, trends which try to anchor scientific certainty in the facts and not in the researcher(s). ${ }^{6}$ I have rather tried to show that the shift to the subject involves some of the most prestigious names of 20th century philosophy of science and it would be therefore futile to try to deny it or to underplay its relevance. One should rather try to understand the phenomenon.

Secondly, I do not recommend or even support the subject-object distinction as a valid tool for philosophical argumentation. In fact, it is problematic. The mere fact that the targets of scientific research are always regarded as 'objects' whilst the knower is only regarded as 'subject' should be

4. Hull (1988) searches for a balance between individual and community from the perspective of an evolutionary understanding of science.

5.For example, Van Riessen (1992) notes a fundamental problem. By grounding scientific knowledge to the subject one moves towards nominalism. In the latter the only forms of universality are found in the subject himself/herself. This means that in concrete reality one meets only individual instances. It is at this point that incongruence is created between science and reality. In fact, scientific knowledge incongruence is created between science and reality. In fact, scientific knowledge aims at the universal, not at the individual and not even at the general. Science is not knowledge of 'this cow' and not even of 'all the cows' in the world. In this way science is no more directed to reality but to the subject and his/her language, concepts and the like.

6.This is the case for example for rationalist authors like Newton-Smith, for realists like Psillos and for the Baynesian school, when it doesn't adopt the subjectivist interpretation of probability. 
criticised. ${ }^{7}$ However, it remains an important distinction that helps us to understand modern (humanist) philosophy and philosophy of science.

After two clarifications, a reflection: the shift to the subject is not something occurring only in philosophy of science. ${ }^{8}$ It is a broader cultural and philosophical problem of Western culture. Also the tension between individual and community is not something occurring only in philosophy of science.

In political theory, for example, initially the Enlightenment emphasised the role of the individual. The latter was regarded as the fundamental 'element' of society, just as the scientific method divided its problems into their simplest 'elements'. It gradually became clear, however, that this introduced arbitrary, even anarchistic inclinations. In fact, the individual 'autos' was not regarded as subjected to any 'nomos' but rather as the source of the law. A solution was sought in anchoring political power in a community. This was perceived as plausible because the community was still regarded as an individual whole and therefore the commitment to the individuality of the Romantics could be preserved. However, that move didn't help with restraining the totalitarian and still arbitrary inclinations of humanist political philosophy and practice (cf. Dooyeweerd 1979:179180). Similar traces of the shift can be detected in many other disciplines.

\section{Searching for the roots}

Now, my simple argument is that if there are so many 'branches' of the same phenomenon in different disciplines, it does make sense to search for the trunk and even for the roots. In other words, looking beyond the borders of the philosophy of science can help with understanding the shift to the subject better.

I do realise that some are inclined to stick to categories holding for the 'history and philosophy of science' and to regard other categories as 'unhistorical' impositions on authors and their works. Such attitude, however, is often just an attempt to 'protect' oneself from acknowledging philosophical or pre-scientific influences, which are experienced as a threat to scientific objectivity, empiricism, anti-metaphysical stances and so forth. For example, those who deny that science is (or should be) influenced by 'frameworks' (e.g. worldviews or other pre-scientific commitments) will probably not be inclined to accept the arguments presented below. ${ }^{9}$

7.Strauss (2009:345-346) reminds us that objects have also subject functions in the first aspects of reality. He adds: 'one may argue that it is an effect of the 'subject-centredness' of modern philosophy (sometimes plainly designated as its subjectivism) that everything different from the human being is turned into an 'object' (ibid:346)

8.Descartes was the first to argue that the ontological 'ingredients' of our world are either mind or extended matter (res extensa). Since then, the subject-object dilemma continued to trouble Modernity. Strauss (1996) offers a short but compelling overview showing to what extent modern philosophy is affected by this shift.

9.Christian scholars are not excluded from this group. For example, Suppe (cf. 1977:125-220; 1996:267-306) and Van Fraassen (2002) are inclined to deny or 1977:125-220, 1996:267-306) and Van Fraassen (2002) are inclined to deny or restrict the influence of 'frameworks on science, due to an anti-metaphysical approach linked to empiricism. For different reasons Brooke is also inclined to
restrict the influence of worldviews (Brooke 1996 and the reply by Wykstra 1996).
TABLE 1: Levels at which the shift to the subject can be detected.

\begin{tabular}{llll}
\hline Levels & Subject & Options & Options \\
\hline 1 & Ground motive (modern) & Nature & Freedom \\
2 & Worldview & Objectivism & Subjectivism \\
3 & Ontology & Realism & Nominalism \\
4 & Epistemology & Realism & Idealism \\
5 & Philosophy of language & Realism & Anti-realism \\
6 & Philosophy of science & Scientific realism & Scientific anti-realism \\
\hline
\end{tabular}

Level 1 is, of course, discussed by Dooyeweerd (1979) and Strauss (2009:615-641) but also by Polanyi (1946:71, 81, 85; cf. Loubser 2013). Bernstein (1985) discusses level 2 and identifies subjectivism and relativism as fundamental options. For an overview of levels 3-5 see Delaney (1985:1-10). McMullin (1984:25) discusses level 6. A useful (historical) overview pointing out the connections between some of the above 'options' is provided by Strauss $(1996: 105,109)$

Nevertheless, when one fails to consider the roots and the trunk of the shift to the subject, one is left with a few leaves, falling from the sky. This seems to me a rather unlikely picture of the phenomenon. Granted that philosophy of science needs the history of science, it also needs philosophy; actually it needs to consider all the levels sketched below (see Table 1) to keep open the possibility of a deeper understanding of the phenomenon to be explored.

In this sketch the categories become 'broader' as one reaches the top levels. The higher levels try to capture something meta-theoretical, pointing towards the 'mentality' of a certain school or thinker in a certain period. However, I am not arguing that once one accepts (for example) objectivism as one's worldview-position the following options will automatically be those in the same column. The situation is more complex: one can be a realist concerning physical laws and a nominalist concerning social norms. Nor am I arguing that one's position is first formed at the highest levels and then 'percolates' down to each lower level. The opposite direction is open as well. Finally, I do not want to suggest that the different levels form a kind of hierarchy. I rather see them as players in a field who, although they may be supposed to hold a certain position, may pass the ball to any other player.

In the next section I sketch my own interpretation of the shift. In doing so, I return to the roots, to the ground motive of nature and freedom. One should note that 'nature' can be regarded as the object-pole of the ground motif (referring to the world of objects) whereas 'freedom' can be regarded as the subject-pole.

\section{Freedom and necessity}

Why would the move to the subject ever be perceived as 'liberating'? Perhaps the question should be preceded by another one: Why should the anchoring to the objects be perceived as 'authoritarian', as something constraining and limiting?

The answer must somehow be related to the idea of 'nature' which emerged in the early humanist reflection: a rather mechanistic network of laws regulating (determining) everything in a chain of causal relations leaving no room 
for chance, indeterminacy or freedom. This conception was inspired by the nature-pole. It soon became clear, however, that in this perspective human freedom was threatened. ${ }^{10}$

In an attempt at escaping such a dead-end, the humanist reflection resorted to the ideal of freedom, the freedom of the subject. Under its wings, 'nature' became an infinite field of possibilities for the expression of the un-constrained human personality. This shift from nature to freedom, however, was not conclusive. It generated a kind of pendulum-dynamic in which a 'return' to the nature motive was to be expected at least in some trends, in some disciplines, in some periods. As Dooyeweerd often notices, giving priority to one pole of a ground motive evokes the counter-pole. In this sort of oscillation between nature and freedom (and implicitly between object and subject), positivism can be regarded as a movement returning to nature, to the objects and their orderliness, to facts speaking for themselves, to a natural world in which the role of the human subject is redundant. Once again, the freedom of the subject is threatened, and this is why the following shift to the subject (the one described in this article and inspired by the freedom-pole) was perceived as a necessary and liberating move.

The quest for a 'liberation' was justified to a certain extent. Yet, as I have argued, after a relatively 'balanced' beginning (see the above sections about Popper and Polanyi), some problems started to emerge. For example, a dialectical tension was gradually (but increasingly) established between the individual and the communal understanding of the subject. Emphasis on the communal subject, on the one hand, seems to erase individual initiative, the possibility of dissensus, pluralism and freedom. On the other hand, emphasis on the individual subject seems to lead to arbitrariness and does not always avoid authoritarian tendencies. Both seem to indulge in some sort of relativism. In addition, the shift to the subject is usually not presented in its full reality but masked by arguments appealing to the one or the other rational necessity, thus failing to disclose its supra-rational commitments. It is from this position that one may start looking at the other problems mentioned above, namely the friction between an individual and a communal understanding of the subject.

It would be beyond the scope of this article to provide a detailed solution to the problems generated by the shift to the subject pointed out in this article. However, a possible way out has already been pointed out by some reformational philosophers. Together with Van Riessen (1992), I am inclined to believe that a solution should not be sought in a counter-return to facts and objects, a 'shift to the object', so to speak. It would be equally inconclusive to try to balance individual and community with a series of weights and counter-weights. It is the subject-object scheme that needs to be replaced.

10.In this section I refer to well-known analyses by Dooyeweerd on the functioning and effects of the ground motifs on cultural developments. I have tried my and to best to make them 'accessible' to the reader who may not be acauanted with Dooyeweerd's works. However, it would be impossible to re-explain in detail and to re-prove all these arguments again. For this, I refer the interested reader to Dooyeweerd's (1984:1) own elaborated explanations.
The locus ordinis for scientific research should rather be found in the structural order for reality (Coletto 2007) in the laws holding for both objects and subjects. It needs to be realised that both objects and subjects are not independent sources of order but are 'subjected' to laws. According to a reformational understanding, in addition, both objects and subjects have subject-functions and object-functions. Objects and subjects, therefore, are not separated by a gulf but 'tuned' to each other and to the same laws. ${ }^{11}$ This perspective harbours the possibility of opening new avenues for contemporary philosophy of science.

\section{Brief conclusion}

This article argued that choosing the subject of knowledge as the locus ordinis of scientific knowledge does not lead to any 'humanitarian' or 'liberating' type of science. On the contrary, it was shown that several problems affect such a position. A tension emerged between an individual and a communal understanding of the subject. It was also argued that the shift to the subject is rarely presented for what it really is and that it would be better understood by looking far deeper and far beyond the narrow borders of the philosophy of science. The roots of the problem are the roots of modernity itself. A solution should not be sought in a simple return to objectivism, but in the replacement of the basic commitments of modernity.

\section{Acknowledgements Competing interests}

The author declares that he has no financial or personal relationship(s) that may have inappropriately influenced him in writing this article.

\section{References}

Barnes, B., Bloor, D. \& Henry, J., 1995, Scientific knowledge: A sociological analysis, Athlone, London.

Bernstein, R., 1985, Beyond objectivism and relativism: Science hermeneutics and praxis, University of Pennsylvania Press, Philadelphia.

Botha, M.E., 1988, 'Objectivity under attack: Rethinking paradigms in social theory-A survey', in P.A. Marshall, \& R. vander Vennen (eds.), Social sciences in Christian survey, in P.A. Marshall, \& R. vander Vennen (eds.), Social
perspective, pp. 33-62, University Press of America, Lanham.

Botha, M.E., 1994, 'Understanding our age: Philosophy at the turning point of the turns? The endless search for the elusive universal', Tydskrif vir Christelike Wetenskap 30(2), 16-31.

Brooke, J.H., 1996, 'Religious beliefs and the natural sciences: Mapping the historical landscape', in J.M. van der Meer (ed.), Facets of faith and science, vol. 1, pp. 1-26, University Press of America, Lanham.

Brown, J.R., 1984, Scientific rationality: The sociological turn, Reidel, Dordrecht. http://dx.doi.org/10.1007/978-94-015-7688-8

Clouser, R.A., 2005, The myth of religious neutrality: An essay on the hidden role of religious belief in theories, rev. edn, University of Notre Dame Press, Notre Dame.

Coletto, R., 2007, 'The legitimacy crisis of science in late-modern philosophy: Towards a reformational response', Ph.D. thesis, North-West University, Potchefstroom Campus.

Collins, H.M., 1992, Changing order, University of Chicago Press, Chicago.

Delaney, C.F., 1985, 'Beyond realism and anti-realism', Proceedings of the American Catholic Philosophical Association, National Office of the American Catholic Philosophical Association, Washington.

Dooyeweerd, H., 1979, Roots of Western culture: Pagan, secular and Christian options, Wedge, Toronto.

Dooyeweerd, H., 1984, A new critique of theoretical thought, Paideia Press, Jordan Station, Ontario.

11.A discussion of the subject-object relationship cannot be expanded further here, but it is introduced very well, for example, by Troost (2012:37-38, 90-96, 289-290, 308-310). See also Dooyeweerd (1984, 2:386ff.). 
Feyerabend, P.K., 1970, 'Consolation for the specialist', in I. Lakatos \& A. Musgrave (eds.), Criticism and the growth of knowledge, pp. 197-230, Cambridge University Press, Cambridge.

Feyerabend, P.K., 1975, Against method: Outline of an anarchistic theory of knowledge, New Left Books, London. PMCid:PMC1681802

Feyerabend, P.K., 1985, Realism, rationalism and scientific method: Philosophical papers, vol. 1, Cambridge University Press, Cambridge.

Gill, J.H, 2000, Michael Polanyi's postmodern philosophy, State University of New York Press, Albany.

Hull, D., 1988, Science as a process: An evolutionary account of the social and conceptual development of science, University of Chicago Press, Chicago. http:// dx.doi.org/10.7208/chicago/9780226360492.001.0001

Kuhn, T.S., 1970a, 'Logic of discovery or psychology of research?', in I. Lakatos \& A Musgrave (eds.), Criticism and the growth of knowledge, pp. 1-23, Cambridge University Press, Cambridge. PMid:4929317

Kuhn, T.S., 1970b, 'Reflections on my critics', in I. Lakatos \& A. Musgrave (eds.) Criticism and the growth of knowledge, pp. 231-278, Cambridge University Press, Cambridge.

Kuhn, T.S., [1959] 1977, The essential tension: Selected studies in the scientific tradition and change, University of Chicago Press, Chicago.

Kuhn, T.S., 1996, The structure of scientific revolutions, University of Chicago Press, Chicago. http://dx.doi.org/10.7208/chicago/9780226458106.001.0001

Lakatos, I., 1970, 'Falsification and the methodology of scientific research programmes', in I. Lakatos \& A. Musgrave (eds.), Criticism and the growth of knowledge, pp. 91-196, Cambridge University Press, Cambridge.

Loubser, R.A., 2013, 'Tracing some consensus on the nature of pre-scientific frameworks in philosophy of science', Acta Academica 45(2), 59-84.

McMullin, E., 1984, 'A case for scientific realism', in J. Leplin (ed.), Scientific realism, pp. 8-40, University of California Press, Berkley.

Polanyi, M., 1946, Science, faith and society, University of Chicago Press, Chicago.

Polanyi, M., 1958, Personal knowledge: Towards a post-critical philosophy, Routledge \& Kegan Paul, London.
Polanyi, M., 1974, Knowing and being, University of Chicago Press, Chicago. PMid:4405943

Popper, K.R., 1961, The poverty of historicism, Routledge \& Kegan Paul, London.

Popper, K.R., 1963, Conjectures and refutations: The growth of scientific knowledge, Routledge \& Kegan Paul, London.

Popper, K.R., 1970, 'Normal science and its dangers', in I. Lakatos \& A. Musgrave (eds.), Criticism and the growth of knowledge, pp. 51-58, Cambridge University Press, Cambridge.

Popper, K.R., 1979, Objective knowledge: An evolutionary approach, Clarendon Press, Oxford.

Popper, K.R., 1983, Realism and the aim of science, Hutchinson, London. PMCid:PMC1550184

Scott, D., 1985, Everyman revived: The common sense of Michael Polanyi, Eerdmans, Grand Rapids.

Strauss, D.F.M., 1996, 'Rationalism, irrationalism and the absolutized horizon of knowledge as ideals of knowledge in philosophy and science', in J.M. van de Meer (ed.), Facets of faith and science, vol. 2, pp. 99-121, University Press of America, Lanham.

Strauss, D.F.M., 2009, Philosophy: Discipline of the disciplines, Paideia Reformational Project, Grand Rapids.

Suppe, F., 1977, The structure of scientific theories, University of Illinois Press, Urbana and Chicago.

Suppe, F., 1996, 'Evaluation of models for interaction between metaphysical beliefs and the natural sciences: The post-Weltanschauungen era', in J.M. van der Meer (ed.), Facets of faith and science, vol. 1, pp. 267-305, University Press of America, Lanham.

Troost, A., 2012, What is reformational philosophy?, Paideia Press, Grand Rapids. Van Fraassen, B.C., 2002, The empirical stance, Yale University Press, New Haven.

Van Riessen, H., 1992, 'Science in the light of the relation between thinking and believing', Tydskrif vir Christelike Wetenskap 28(1), 27-95.

Wykstra, S.J., 1996, 'Should worldviews shape science? Toward an integrationist account of scientific theorizing', in J.M. van der Meer (ed.), Facets of faith and science, vol. 2, pp. 123-171, University Press of America, Lanham. 